\title{
From Hijazi beginnings to Classical Arabic
}

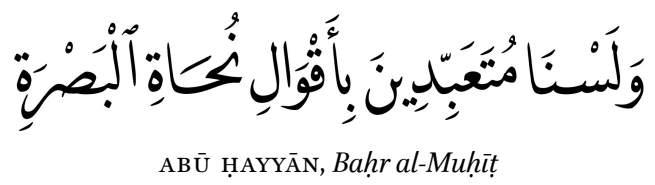

The previous chapters have been concerned with four general topics. The first of these asked the question what the Sarabiyyah was according to the earliest grammarians-demonstrating that these early grammarians had a much less prescriptive view of the language than what we later come to define as Classical Arabic. This is cause for us to rethink what it means for the language of the Quran to be the Sarabiyyah, and forces us to ask a more precise question: what was the language of the Quran really like, which of the myriad competing features of the Sarabiyyah were the ones that were proper to the language of the Quran, if any?

Turning to the Quranic reading traditions, we find that far from giving a uniform answer as to the linguistic features of Quranic Arabic are, they frequently employ many different forms reported by the grammarians. This shows that in this period the concept of what the farabiyyah was and was not, was still very much under debate. Moreover, it was shown that the linguistic system that the Quranic reading traditions reflect do not seem to form consistent linguistic systems that agree very well with the Arabic dialects as described by the grammarians. Moreover, they frequently go beyond what falls under the purview of the grammarians, incorporating linguistic features that must be thought of as artificial. Because of the great amount of disagreement between the readings, as well as their artificial nature, the Quranic readings cannot be seen as giving a clear and undeniable insight into what the language of the Quran truly was at the time of its composition.

Subsequently, I proposed that we do away with the mixed signals that come in through the Quranic reading traditions, and instead focus on the linguistic features that can be deduced from the one part of the Quranic corpus that clearly stems from the early Islamic period, namely the Quranic Consonantal text of the Uthmanic Archetype. Once we look at the features that can be 
deduced from this earliest stratum of the Quran, a surprisingly consistent picture emerges: Nearly all isoglosses that can be deduced from the QCT, align with Hijazi Arabic.

The fact that such a consistent picture emerges from the study of the QCT is not at all obvious from the perspective of the tradition. The Arabic philological tradition was not troubled by features in the Quran being mixed and matched from a variety of different dialects, and there was no focus on arguing that whatever occurred in the Quran had to be Hijazi Arabic. The fact that, despite this, such a clear picture presents itself suggests both that we should take the QCT as a linguistic source seriously, as well as conclude that the language of the Quran has been reworked and 'Classicized' over time, to yield the much more Classical looking forms of Arabic in which the text is recited today. In the previous chapters, I have demonstrated that there is in fact quite a lot of evidence in the way the readings behave as well as in the literary sources that this is indeed what happened: the readers were actively aiming to make the language of the Quran more in line with what they considered to be the proper Sarabiyyah. This can be clearly seen from the fact that readers were concerned with questions of pseudocorrect application of the hamzah - a feature said to be absent in the language of the Hijaz. But also, perhaps more controversial, I suggest we can see traces of the Classical Arabic case system having been imposed onto the original language as reflected in the QCT, which had lost most of its word final short vowels and tanwin.

The title of this book is "Quranic Arabic: from its Hijazi Beginnings to its Classical Arabic readings." Having arrived at the end of this work, it seems worthwhile to provide here a chronological reconstruction of the development of the language of the Quran up until the language of the reading traditions as we see it today, and finally, place the emergence of a standard Classical Arabic within this framework.

\subsection{The Prophet's Career}

We do not have a perfect direct source of the composition of the Quran as it was recited by the prophet Muhammad during his career. Nevertheless, considering that the Quran is a rhyming text, and the QCT normally agrees with the phonetics that seem to be reflected in the rhyme, it seems fairly safe to say that the language of the QCT was close to the language Muhammad would have used during his career as a prophet in the early seventh century. The language of composition would not have been Classical Arabic, but instead the local vernacular of Mecca and/or Medinah: Hijazi Arabic—lugat Pahl al-Hiğāz. 
Although the Quranic verses that affirm that the Quran itself and its language are farabiyy have sometimes been interpreted as the Quran affirming that it is composed in Classical Arabic - or at least a high language distinct from the vernacular, I believe that Al-Jallad's (2020b) analysis of the Sarabiyy verses is much more probable. He suggests that these verses are specifically meant to affirm that the Quran was revealed in the local vernacular in contrast to the scriptures of, for example, the Jews and Christians which would have been Pa९ğamiyy 'foreign, unintelligible' which is especially clear in Q16:103,

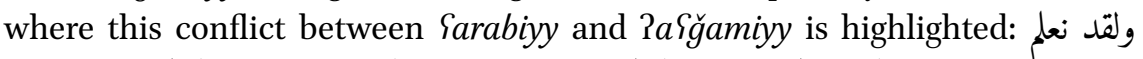

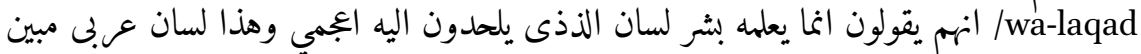
naSllam annahum yâqūlūn innamā yưallimu-h bašar; lisānu lladīi yulḥidūn ilayh a ğgamī wa-hādā lisān Yarabī mubīn/ "We have certainly learned that they say that it is just a human that is teaching him; but the language which they refer to is foreign, while this is the clear Arabic tongue."

The dichotomy between Classical Arabic and the "vernacular" should not be seen in such stark terms as it often is within the field. Just because the Quran is composed in the local vernacular does not mean it cannot have retained many of the highly archaic features that we associate today with Classical Arabic, rather than the modern vernaculars. The idea that the "vernacular" nature of the language needs to imply the loss of these archaic features-leading to an rapprochement to the modern vernaculars - is unwarranted, but a view that appears frequently in the literature (e.g. Blau 1977; Zwettler 1978). Whatever vernacular was spoken in the Hijaz in the early seventh century would, of course, quite likely be much more archaic in many regards than those spoken more than a millennium later. Vollers' (1906) theory posited that the Hijazi vernacular was very close to the widespread modern vernaculars such as the Egypto-Levantine dialect bundle, having lost case distinctions in all environments. The evidence does not support such a conclusion.

\subsection{The Uthmanic Recension (ca. 3 OAH/65 O CE)}

While the details of the when and by whom of the canonization of the Uthmanic text type have been debated for some time, a new focus on the use of primary source material in the form of early Islamic manuscripts has made it quite clear that this canonization was most likely undertaken during the reign of the third caliph Suțān b. Saffān, who had four copies made that were distributed to Kufa, Basra, Syria (likely Homs, see Sidky 2021, 171-174) and Medina. The orthography of this archetype has been extraordinarily wellpreserved and quite clearly reflects the Hijazi dialect—something universally 
acknowledged, even by scholars who did not conclude from this that the language it intended to represent was also Hijazi.

The clear agreement between the orthography and the Quranic rhyme shows that the language of the Uthmanic recension was certainly not very far removed from the language of the original composition. Likewise, the orthographical and linguistic features as found in the Uthmanic recension show clear and obvious connections to the administrative language of the early Arabic papyri.

The various reports that the Quran was revealed in the language of the Qurayš and that futmān explicitly ordered the Quran to be written in the language of the Qurayš should, in light of the discoveries presented in this work, be reevaluated. Kahle brings one such a report, quoted by al-Farrā?:1

'Umar b. al-Khaț̣āb heard a man reading 'attā hina (sic) in the meaning of hattā hìna. He said: 'Who taught you to recite thus?' He said: "Abdallāh b. Mas'ūd.' So, he wrote to 'Abdallāh b. Mas'ūd: 'The Koran came down in the language of the Kuraish and it came not down in the language of the Hudhail. So, do you teach men to recite it in the language of the Kuraish and not in language of the Hudhail.'

Zwettler, and with him Rabin do not accept that the Quran was composed in the language of the Qurayš, and instead believe the Quran was composed in the 'poetic koiné. Zwettler reads part of the section that Kahle translates from al-Farrā? as evidence for this. Al-Farrā? argues that the Qurayš dialect was superior to all others, and interestingly cites a couple of reasons, pointing out it lacks the San Sanah of the Tamim (pronouncing Yayn as ?alif), nor the Kaskasah

1 While the attribution of this discussion to al-Farrā? is certainly how it appears in the manuscript CBL MS. Arab. 705, a work on Quranic verse counts falsely attributed to al-Farrā?, one has to wonder about the accuracy of this attribution. Larcher $(2005,802 \mathrm{f}$.) speculates that the text is an extract from al-Farrā?'s Lugiāt al-Quriān, but since Larcher's writing, that text has now become available to us. If it was ever part of that text, it has not come down in the recension we have access to today. There are some reasons to doubt the attribution of the citation to al-Farrā?: it does not seem to be quoted in any other known works even though al-Farrā? gets cited so frequently in a large variety of medieval works, that a large portion of Lugāat al-Quriān and al-Maৎānī could be reconstructed from citations alone (and for Lugāt al-Quriān, Rabin at times indeed does, see the discussion on hollow root Pimālah in § 5.9). It would be quite surprising for an account as interesting for linguistic ideologies as this one to not be cited at all in works perhaps more relevant to linguistic questions than a book on verse counts. I will proceed on the assumption that the quote indeed comes from al-Farrā?, though the identity of the author of the quote does not significantly impact our conclusions here. 
of Rabīiah (pronouncing the pausal 2sg.f. ending $-k i$ as $-k i s^{2}$ ) nor the $k a s r$ of the Qays in tiSlamüna, tiSlam (Barth-Ginsberg alternation) and biSir, ši iir (for baSir and ša iir, see § 2.2.3).

It is an anachronism to think that these features, absent in the modern standard of Classical Arabic, where absent in the poetic koiné/Sarabiyyah, as they are described in detail by Sỉbawayh and other early grammarians. It would, moreover, be a mistake to take this discussion of al-Farrā? to equate the most eloquent form of the Sarabiyyah - the one that later becomes to standard Classical Arabic - with the dialect of the Qurayš. In fact, when we examine alFarrā?'s writing in a broader perspective including his Lugāa al-Qur?ān and Maৎānī al-Quriān, he clearly has no issue assigning linguistic features to the Qurayš that he almost certainly did not employ himself in Quranic recitation. For example, he reports that the Qurayš did not apply vowel harmony to of the third person pronouns -hü, -humā, -hum and -hunna (al-Farrā? Luġät, 10f.), that they did not have the front rounded vowel for passive hollow verbs qüla (al-Farrā? Luḡät, 14), but rather qüla and that they read mustahzi?ūna without hamzah as mustahzūna (al-Farrā? Luġāt, 15). His teacher, al-Kisā?ī, recites the Quran with the non-Qurašì option in all three of those cases. The other Kufan reciters have the Quraši option for qüla, but for the other options are non-Qurašī. Al-Farrā? is a transmitter of al-Kisā?ī's reading and clearly sees no problem in terms of eloquence of reading in such a manner, as he does not explicitly denounce any of these manners of readings, not in his Luga àt alQur?ān, nor in his MaYānī al-Qur?ān.

Clearly, to al-Farrā? there was no inherent contradiction between the statement that the Quran was revealed in the dialect of the Qurayš, and the Quran being recited in something that was self-evidently to al-Farrā? not the language of the Qurays. ${ }^{3}$ This does not prove that the language of the Quran was Classical Arabic/poetic koiné, as Zwettler would have it. It proves that the original language of recitation was not relevant to how the Quran was recited. This makes it significantly more plausible that the traces of Classicization of the language of the Quran that we see were considered acceptable to this late second century AH authority.

2 This is sometimes understood as referring to a palatalization of pausal $-k$ to $-t^{s}$. I find the evidence for this not particularly compelling, and will stick to the literal reading here.

3 On the apparent contradiction between Qurayš being the most eloquent of languages, and at the same time the most eloquent language, the farabiyyah, being nothing like the language of the Qurayš see the excellent discussion by Larcher on this text by al-Farrā? in relation to a similar text by Ibn Fāris (Larcher 2005). 
Clearly, not all grammarians were equally satisfied with this dialectal identification of the Quran's language. In the interpretation of the sabSat Pahruf hadìt, Rabū Yubayd al-Qāsim b. Sallām $(\mathrm{d} .224 \mathrm{AH} / 838 \mathrm{CE})$ reports that the much debated Pahruf refer to seven different dialects of Arabic, Ibn al-Ǧazarī ( $§ 65)$ quotes Pabū Yubayd as claiming these seven dialects were: Qurayš, Hudayl, Taym al-Rabāb, al-Pazd, Rabīiah, Hawazān and Said b. Bakr, but no such specific reference is given in Pabū Yubayd's Faḍ̂̄il al-Qur?ān, where he does mention that the Quran was revealed in seven dialects (attributing this claim to the companion Ibn Sabbās), without specifying which seven those were (?abū Subayd Fad̄āiil al-Qur?ān, 340).

Regardless of the historicity of al-Farrā?'s report, we can conclude that whatever language the Quran was composed in, the Quranic reading traditions are not only linguistically clearly not a guide to what that language of the Quran was (as I have argued in chapter 3), but also that these early influential authorities seem to agree with that conclusion.

While the above report, cited by al-Farrā? without ?isnād, may very well be late, there is another well-attested bundle of reports about the process of the Uthmanic recension, which seems to have been extraordinarily early, Motzki (2001) through his detailed isnad-cum-matn analysis shows that the common link of this report is Ibn Šihāb al-Zuhrī (d. 124AH/741-742 CE). This report usually includes the mention that Sutmann's recension of the Quran should be written in the dialect of the Qurayš because it was revealed in their language, and that part of the report independently goes back to our common link Ibn Šihāb. ${ }^{5}$

Thus, through Pibrāhīm b. SaYd and ŠuSayb ${ }^{6}$ both on the authority of al-Zuhrī we get a virtually identical report:

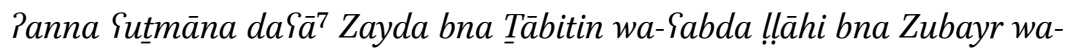

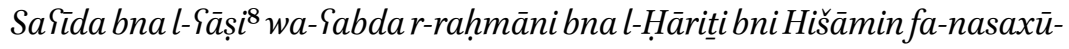
hā fì l-mașāhif. Wa-qāla Suțmānu li-l-rahți l-qurašizyīna ț-talātah: Pid̄āxta-

4 Note that this is in direct conflict with the report of Sumar cited by al-Farrā?.

5 The version reported by al-Tabarī lacks this section (Comerro 2012, 37). The partial common link of al-Ṭabarī's version is Yūnus, transmitting from the common link Ibn Šihāb al-Zuhrī (Motzki 2001, 25).

6 The partial common link of Šufayb's version forms a partial common link one generation later, at Pabū l-Yamān (Motzki 2001, 25).

7 Šuiayb opens with qāla fa-Pamara Suțān "Uthman said and ordered" instead.

8 Šufayb reverses the two preceding figures in the order they are mentioned. 
laftum Pantum wa-Zaydu bnu T̄äbitin fi šay?in mina l-qur?ān,,${ }^{9}$ fa-ktubü-hu bi-lisāni Qurayš, fa-Pinnamā nazala bi-lisāni-him. ${ }^{10}$ fa-faSalū d̄ālik. ${ }^{11}$

Suțmān called Zayd b. Tāābit, Sabd aḷāh b. Zubayr, SaYīd b. Al-Yāṣ and Sabd al-Raḥmān b. al-Ḥārit b. Hišām — they copied the manuscripts of the Qur?ān. Suțān said to the Qurashis (everyone but Zayd): If you disagree with Zayd $b$. Tabit on anything in the Quran, write it down in the dialect of the Quraysh, because the Quran was revealed in their language. And so, they did that

Saḥ̄h al-Buxārī: al-Manāqib 61, Bāb Nazala al-Qurīān bi-Lisān Qurayš, \#35०6; Faḍāill al-Quriān 66, Bāb nazala al-Quriān bi-Lisān Qurayš wa-l-Sarab, \#4984

Schwally (Nöldeke et al. 2013, 260) dismissed the historicity of this part of the report as an outright forgery, saying: "generally, any tradition connecting the 'Uthmānic text in any way with dialectal questions must be rejected, since the Koran is not written in a local dialect at all but rather has a language identical to that of the pre-Islamic poems." While this has been the communis opinio before him and after him, I hope that the current work has shown that the identity of the Quranic language with poetry has so far only been asserted and has not been demonstrated, and that the QCT indeed quite clearly reflects Hijazi Arabic. Considering the earliness of the report and how well it aligns with the facts of the early Quranic manuscripts, we can carefully conclude that this report may very well retain a historical memory of the original language of composition of the Quran.

\subsection{The Era of the Readers (ca. 4O AH-25OAH)}

While the original language of the Quran, as shown by the QCT and affirmed by the tradition appears to have been Hijazi Arabic (or specifically Qurashi), at some point linguistic norms - at least in the recitation of the Quran — shift drastically, giving rise to the classicized reading traditions that we know among the canonical, and non-canonical readers alike.

9 ŠuYayb has fi Sarabiyyatin min Sarabiyyati l-qur?ān "on the Arabic from among the Arabic of the Qur?ān" instead.

10 ŠuYayb has fa-Pinna l-qur?āna Punzila bi-lisāni-him "for the Quran" instead.

11 ŠuYayb lacks dālika. 
Al-Jallad (2020b, 69f.) draws a tentative initial history of this development. He suggests that Old Hijazi, the language of the QCT, was the literary and prestige dialect of the Medinan state, and continued to be so as it transitioned into the early Umayyad empire. He suggests that in the Umayyad period another literary form of Arabic gains prestige, namely the language of the Qașidah, with its strict metered and rhymed system. While the exact linguistic features of these odes are obscured by the inexorable forces of revision towards the later literary standard, ${ }^{12}$ one feature is undeniable: the system of final short vowels and tanwin forms an integral part of its structure confirmed by the rhyme and metre.

It seems possible that this new literary standard that enters into the sociolinguistic arena, vying for prestige should be identified as the dialect of the MaYadd. Al-Jallad follows Peter Webb's highly thought-provoking observation that the main label of group identity in the pre-Islamic qașīdahs is MaYadd (Webb 2017, 70 ff.), who these MaYadd were and how their qașidahs gained prestige in the Umayyad period is a question that we hope Al-Jallad will address in the future research project he mentions in his book (Al-Jallad 2020b, 69).

However we interpret this relation to Mafadd exactly, one thing is abundantly clear and I follow Al-Jallad completely in his conclusion: "the Qașīdah belong to a different literary culture than that of the Higāz, as its form is not found in the Quran. And even though the Quran refers to poets, there [is] nothing to suggest that these poets were producing poems belonging to the same style as the pre-Islamic Qașidah." In a footnote he adds: "the very fact that the Quran had to tell its audience that the speaker was not a "poet" suggests a structural similarity between the text and what the audience would have considered poetry. If the Classical Qașīdah was the prototype, no such warning would have been necessary."

When exactly this literary variety starts to play a central role in influencing Arabic literary prose is frustratingly difficult to answer, due to the dearth of primary source material that dates from the period and is likewise vocalized, but when it comes to the period that this "qașidah register" starts playing a role in Quranic recitation puts us on firmer ground. The transmission of many Quranic readers is rather strong, and there can be little doubt that the form in which they have been transmitted to us is very close to how they actually recited the Quran.

The earliest reader by far would certainly be Ibn Yāmir, who is said to have lived from 8 to $118 \mathrm{AH}$, but his transmission is problematic for a variety of rea-

12 Something already clearly noticed and impeccably formulated by (Nöldeke 1910, 3). 


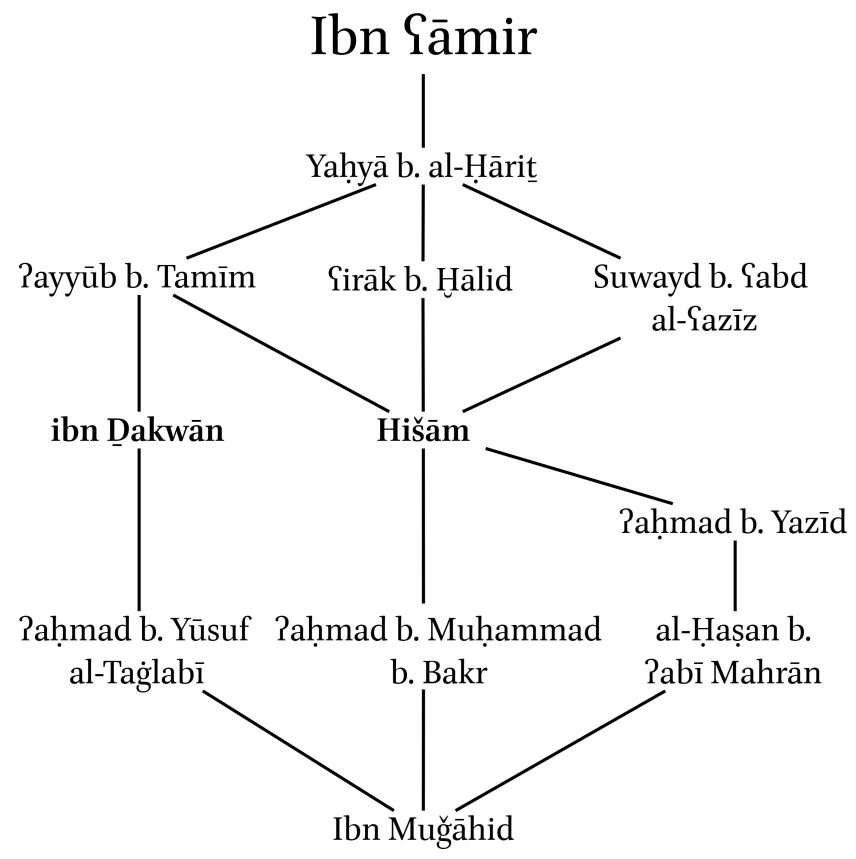

FIgURE 3 Pisnād of Ibn Yāmir as reported by Ibn Muǧāhid (85-87)

sons. First, his astounding age of no years should raise some eyebrows, but even granting that, his transmission has only come down to us through one transmitter, Yahyā b. al-Ḥāriț (d. $145 \mathrm{AH}$ ) and the two canonical transmitters (Hišām, 153 AH-245 AH and Ibn Dakwān, 173 AH-242 AH) are removed two more generations from Yahyā sharing, partially, the same teachers. So, this reading may have taken its Classical shape as late as the mid second century AH.

al-Ḥasan al-Bașrī (11OAH) and Ibn Muhayșịn al-Makkī (d. 123AH) along with the canonical reader Ibn Katīir (d. 122 AH) (see al-Dahabī 46, 69, 89) make up the next group of earliest readers, and their readings can be more securely attributed to their lifetimes. Therefore, somewhere in their lifetimes this register formerly proper to the pre-Islamic Qașidah had gained enough prestige to come to be accepted as part of the prestigious Quranic recitation.

The bulk of the canonical and well-attested non-canonical readers alike, have their death dates all throughout the middle of the second until the middle of the third century. ${ }^{13}$ It seems reasonable to conclude that recitation with PiSrāb and tanwin (and seemingly at least some amount of the application of

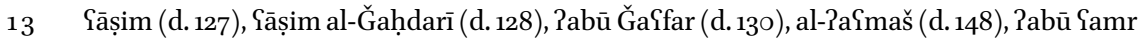


the hamzah) rose to dominance in this period. At its earliest, at the start of the Umayyad period, but probably became firmly established some decades after the beginning of the Umayyad period (perhaps around $8 \mathrm{oAH}$ ).

This seems to be independently confirmed by the primary source material in the form of early Quranic manuscripts. The earliest manuscripts, those that can be dated to the seventh century, lack any form of vocalization signs and purely reflect the standard Uthmanic text, a consonantal skeleton (e.g. CPP, BL, Arabe 330g, Birmingham, Cadbury Research Library, Islamic Arabic 1572b). By the 8th century a system of red dots developed to write the vowel signs. Of course, the absence of vowel signs does not necessarily suggest that in this period the Quran was still recited in a purely Hijazi manner, but it stands to reason to consider the development of the vowel signs to suit a need, and this need would have quite naturally been to aid recitation in the linguistic style of the now popular Qașīdahs.

The fact that vocalization in manuscripts is primarily focused not on marking the word internal vowels - that part was clearly considered quite uncontroversial — but to primarily mark (1) word final short vowels and tanwin and (2) The place of the hamzah, is a strong indication that it was specifically these two features that were salient and of prime importance to be conveyed in this period of developing reading traditions.

For an illustration of this system I have transcribed below a single page of R 119, f. 23a (for the photo see Déroche (2014), fig. 17). Every section in bold is expressed in the vocalization. Of the 112 cases of vocalization, only 23 are used to mark word-internal vowels, the remaining 89 express stem-final short vowels, Pi irāb/tanwīn, or hamzah.

1. wa-lā liyahdiya-hum țarīqan. Pillā țarīqa ğahannama xālidīna fìhā Pabad-

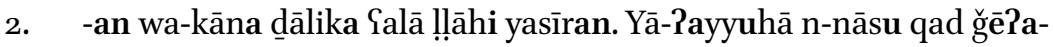

3. kumu r-rasūlu bi-l-haqqi min rabbi-kum fa-Pāminū xayran lakum wa-Pin

4. yakfưū fa-Pinna lillāhi mā fì s-samāwāti wa-l-Parḍi wa-kāna

5. ḷāhu Yalīman hakīman. Yā-Pahla l-kitābi lā tag̉lū fỉ dīnikum wa-

6. lā taqūū Salā ḷāhi Pillā l-ḥaqqa Pinnamā l-masīhu Yīsā bnu

7. maryama rasūlu ḷ̣āhi wa-kalimatuhū ?alqā-hā Pilā maryama wa-rūḥun

8. minhu fa-Pāminū bi-llāhi wa-rusulihī wa-lā taqūlū talātatun-i ntahū

9. xayran lakumū ?innamā ḷạhu ?ilāhun wāḥidun subḥānahū ?an yakūna lahū wa-

10. -ladun lahū mā fì s-samāwāti wa-mā fì l-Parḍi wa-kafā bi-

(d. 148), Ḥamzah (d. 156), Nāfiৎ (d. 169), Sallām (d. 171), al-Kisāīī (d. 189), YaYqūb (d. 205), Pabū Yubayd al-Qāsim b. Sallām (d. 224), Xalaf (d. 229), Rabū Ḥātim al-Siğistānī (d. 255). 
11. -llāhi wakīlan. Lan yastankifu l-masīhu ?an yakūna Sabdan li-llāhi wa-

12. lā l-malāiikatu l-mufarrabūna wa-man yastankif Yan Sibādatihī

Of course, it is frequently very difficult to be establish whether the red dotting is in fact contemporary with the writing of the text, and we only become more certain of this when we reach manuscripts of the classical Kufic B.II and D styles, which generally date to around the middle to end of the third century AH (Déroche 1992, 36 f.), where the vocalization appears in virtually all manuscripts in these styles, clearly indicating that they were considered an integral part of the manuscript's creation.

Addition of vocalization is certainly unlikely to post-date the third century, as by the early fourth century Ibn Muğāhid canonizes the seven canonical readers, after which these rapidly become the dominant readings reflected in manuscripts. Before this canonization, however, more often than not the readings represented in these manuscripts are clearly non-canonical, and unlikely to have been added to such manuscripts in, say, the fourth century AH or later.

Several manuscripts show nascent forms of the vocalization system, expressing hamzah in ways that are somewhat different from later manuscripts. Most prominent is Kairouan, Musée des arts islamiques R 38, a manuscript which from its ornamentation and script style should clearly be considered part of the imperial Umayyad Qurans, which uses not red dots but red dashes, and seem to predate the innovation of doubling the vowel sign to mark tanwin, as it uses only a single dot where one expects two to be written. It stands to reason to consider this a very early example of this system, and may very well be contemporaneous to this manuscript, which likewise follows a non-canonical reading.

BnF Arabe 334a, studied by Cellard (2015) and edited by Van Putten (2019a) is a more developed system of vocalization, already using doubling of the vowel sign to use nunation, but employing not red dots but somewhat thicker red dashes than R 38. Also, its system of marking the hamzah seems to be somewhat different than that in other vocalized manuscripts. The vocalization, as shown by Van Putten (2019a), follows a non-canonical but perhaps Hijazi reading style, with as a prominent feature the absence of any form of vowel harmony on the third person pronominal suffixes. While lack of harmony in the pronouns becomes extraordinarily popular in the B.II manuscripts, those consistently harmonize bihī only (van Putten and Sidky forthcoming), this manuscript also leaves that unharmonized as $b i h \bar{u}$. These features likewise give it the impression of being rather more archaic than the regular vocalization style.

While the details differ on how the hamzah, rifräb and tanwin is expressed in these manuscripts, they likewise agree that the system is only rarely employed 
to express word-internal short vowels. I believe that we can place the rise of the vocalized manuscript, and especially the one with a focus on the final short vowels and hamzah, in the Umayyad period, continuing into the Abbasid period, contemporaneous with the rise of activity of Quranic readers.

It is of course also quite significant that the eponymous readers to which all these readings are attributed come from this crucial era in the early 8 th to 9 th century. It would have been extraordinarily attractive to attribute the readings not to historically rather insignificant figures like the eponymous readers, but rather to companions of the prophet or the prophet himself, but this does not happen. This is because it is precisely these readers that constructed these classicized readings in this era.

A final, but much more scanty piece of evidence for the shift from a classicization of the Quran may perhaps be found in the grammatical terminology as it is used by the early exegetical works as studied by Versteegh (1993). A striking difference between the very earliest transmitted tafsir of Muğāhid b. Ğabr (d. 104/722) compared to some of the slightly later exegetes such as Muhạammad b. al-SāPib al-Kalbī (d. 146/763), Muqātil b. Sulaymān (d. 15o/767) and Sufyān al-Tawrī (d. 161/778) is exactly the complete absence of the former of any terminology for Pißrāb and tanwīn, and even in Sufyān al-Tawrì's commentary such terminology is almost entirely absent, he only uses the verb nawwana "to apply nunation" once (Versteegh 1993, 113). This is quite different from Muhammad al-Kalbī who shows a concern for variant readings and in discussing them displays a full set of terms for final short vowels (Versteegh 1993, $125 \mathrm{ff}$.). It is difficult not to notice that Muhammad al-Kalbī's is exactly the generation of many of the great Quranic reciters such as Pabū famr (d. 154/770) and Yāșim (d. 127/745) and Nāfi (d. 169/785), while Muğāhid clearly precedes them, and thus perhaps also the widespread classicization of the language of the Quran.

This era marked an explosion of different linguistic forms, and a negotiation of what the linguistic features of the Sarabiyyah were going to be. This much is already clear from the disagreement on the linguistic details between the canonical readers (as we saw in chapter 3 ), but also other non-canonical readers show an even broader amount of linguistic variation than is allowed within the canonical ten. Also, within the vocalized Quranic manuscripts, a wealth of different forms and unusual recombinations of features are found. ${ }^{14}$ What the Sarabiyyah was, was not yet straightforward, and this period must be seen as

14 For an in-depth study of just one part of the variation of linguistic systems, namely the pronouns, both in the transmitted tradition and the manuscripts see Van Putten \& Sidky (forthcoming). 
a negotiation towards a new standard, truly only one central feature remains constant throughout this experimentation and that is that the final short vowels and tanwin, the one feature that is perpetuated by every line of the new central literary form: the qașidah.

\subsection{Crystallization of Classical Arabic (ca. 250-35 AH)}

There is a reason why we speak of Classical Arabic in a much more restricted sense than the Sarabiyyah that the early grammarians sought to describe. Indeed, at some point, the negotiation of what the Sarabiyyah starts to crystallize and a fairly uniform system emerges which is more or less identical to grammar books such as Fischer, Wright and Thackston. When exactly this complete crystallization takes place, is as of yet, not entirely clear. Research into the linguistic norms of non-Quranic literary manuscripts of the third and fourth centuries is still a desideratum. But I will provide some initial observations.

The papyrus copy of al-ǦămiS by Ibn Wahb (d. 197AH), copied in $275 \mathrm{AH} /$ $889 \mathrm{CE}$ and published by David-Weill (1939) is remarkable for being strikingly unclassical in its language. Despite being unvocalized, it has many features that would not be considered part of the Classical Arabic language that we know today. Middle Arabists such as Blau (1999, Appendix I) have often taken this work to be a reflection of 'Middle Arabic', a form of Arabic that mixes Classical Arabic and colloquial features. However, if Blau is right to suppose that the unusual linguistic features present in this manuscript are rather reflective of the peculiarities of Ibn Wahb's Arabic rather than of its copyist, we are dealing with a manuscript stemming right from the period that the parameters of the literary language were still being negotiated. Regardless of whether some of the unusual features of Ibn Wahb's text as the result of interference of the author's colloquial Arabic, seeing his deviations from Classical Arabic as deviations from an established standard is anachronistic. For example, it is highly

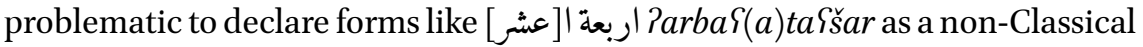
form (Blau 1999, 124), while Pabū Ğaffar (d.130 AH) who recites Q74:30 تسعه عشر as tis§ata §̌̌ar (Ibn al-Ǧazarī, §3205) which would make it Sarabiyyah by definition. Clearly, the jury was still out on whether such a form was to become part of Classical Arabic.

The copy of Pabū Subayd al-Qāsim b. Sallām's (d. 224AH) Garīb al-Hadīt, copied in $252 \mathrm{AH}$, and with that the oldest known dated paper manuscript in Arabic, held at the Leiden University Library under the shelf mark Or. 298 is another data point worthy of examination. This manuscript is vocalized with 
the modern vowel signs that are clearly contemporary with the main text, and this gives us an insight into some of the linguistic features. Many of the features that we associate with standard Classical Arabic are present, even though the orthography is exceptionally archaic, thus $? \bar{\imath} u x \bar{a}-h \bar{a}$ and $\vec{\imath} \bar{u} l \bar{a}-h \bar{a}$ are spelled with typically Quranic orthographic practice of using $y \bar{a} ?$ for the ?alif maq-

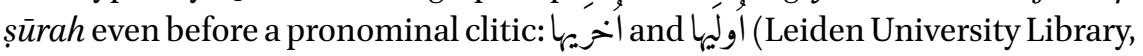
Or. $298,{ }^{15} 2$ r, l. 13). But despite this spelling, which has sometimes been interpreted as indicating Pimälah, the spelling with fathah before this ?alif maqșūrah suggests that it already employed the standard Classical Arabic $-\bar{a}$. Likewise, the plural pronouns are short, and they undergo vowel harmony, and the appearance of hamzah appears to be quite conservative.

But a question is, to what extent these features that are present in the manuscript are indicative of a crystallization of the Classical norms. We are lucky enough to have a transmission of Pabū Subayd's own reading of the Quran, and for each of these features he indeed follows the Classical norm. Yet there are indications that not all users of the literary Arabic language in the early third century would stick perfectly to this Classical Arabic norm. For example, in his Quranic recitation, Pabū Ḥātim al-Siğistānī (d. 255AH) still has the non-standard Classical Arabic lack of vowel harmony after-ay for the plural pronoun, i.e. Salayhum but fihim, bihim (van Putten and Sidky forthcoming). Whether Pabū Hātim would have employed such pronominal behaviour outside of his reading tradition and in his Classical Arabic prose, is sadly something that cannot be confirmed, as we lack any autographs, or in fact any copies at all of his works, but I see little reason assume a difference between recitation and Classical Arabic prose a priori.

What is definitely clear is that about a century later, in Ibn Xālawayh's Kitāb al-Badīs, of which we have a copy from his death year (380AH, CBL Ar 3051), all the features part of the standard Classical Arabic have been firmly established. ${ }^{16}$ This is independently confirmed by the literary tradition, the contemporary author Ibn Mihrān (d. 381AH) in his description of the pronominal system of the Quranic readers, strikingly different from most other sources in the genre, only mentions deviations from the Classical norm, leaving it implicit that anyone whom he does not mention explicitly, simply has the Classical Arabic harmonizing short suffixes (see van Putten and Sidky forthcoming).

15 For more information on this manuscript see Witkam (2007, 1:149-152).

16 Although occasional surprising variants show up, still from a normative perspective, for

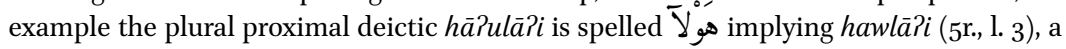
variant recognized to exist by Al-Farrā? (lughāt, 22), but not generally considered part of the normative classical register. 
It seems then that quite soon after (if not already during) the period I labelled 'the Era of the Readers' the typical features that we now associate with standard Classical Arabic became firmly established. Some of the typical features that became fixed, which at the time of the early readers and grammarians were clearly still up for debate are:

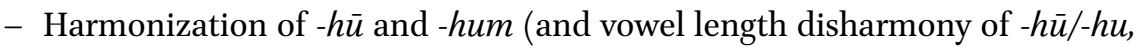
$-h \bar{\imath} /-h i)$, a feature generally associated with the Najdi dialects.

- Short plural pronouns, rather than the long forms -humū, 'antumū etc.

- Conservative syllable structure, typical for the Hijazi dialects (rusul and kalimah, not rusl and kalmah, kilmah).

- Conservative retention of the hamzah, typical of Najdi dialects.

- Generalization of the $a$-vowel in prefix conjugation typical of the Hijaz, rather than the Najdi forms like tiSlamu.

- Absence of $i$-umlaut Pimālah, a feature associated with Najd.

- Complete loss of the fourth phonemic vowel è for III-y nouns and verbs, considered to be a Najdi feature by the grammarians, but clearly also part of Quranic Arabic originally.

This rather chaotic combination of features of standard Classical Arabic should make it quite clear that the rather popular notion that Classical Arabic is primarily influenced by the Najdi dialects is not really borne out by the evidence. While the vowel harmony of the pronouns and the conservative use of the hamzah are indeed striking features associated with Najd, many other features typical of Najd like the far-reaching syncope of $i$ and $u$ in open syllables, the front vowel prefixes in the verb and Pimälah are entirely absent.

Moreover, much of the morphology that is reflected by the actual consonantal skeleton, such as the shape of the deictic pronouns is almost invariably in agreement with the Hijazi forms, while the Najdi $\underline{d} \bar{a} k a$ occurs occasionally in Classical Arabic prose, $\underline{d} \bar{a} l i k a$ far outnumbers it, and tīka/dìka, hād $\bar{\imath}$ and $(h \bar{a}-)$ Pula instead of tilka, hā Contrary to popular belief, I would therefore also say that it is in fact Hijazi Arabic that is the main contributor to the phonology and morphology of Classical Arabic rather than Najdi Arabic. This is, no doubt, due to the massive influence the Quran had on the emerging literary tradition of Arabic. That this influence has not been realized sooner, primarily seems to rest on the fact that whenever the Quran agreed with standard Classical Arabic it has been considered to be normal and unremarkable and in line with the conclusion that the Quran was composed in standard Classical Arabic.

Despite a crystallization of most of the main Classical Arabic norms being complete around the 4th century $\mathrm{AH}$, it remains possible to encounter nontextbook features occur in perfectly Classical Arabic prose until surprisingly 
late. While certainly outside the scope of the current book, let me highlight a few salient cases that I have noticed.

Syncopation of huwa and hiya after wa-, fa-, la- to wa-hwa, fa-hya (§ 2.2.4.3) sticks around in Classical Arabic prose until surprisingly late. For example, al-Mağmūi al-Rašídiyyah (BnF Arabe 2324) dated to 710 AH regularly has this syncope throughout its text (see 3r, l. 12; 1or, l. 10; 22r, l. 3; 34v, l. 16; 4OV, l. 6; 5ov,

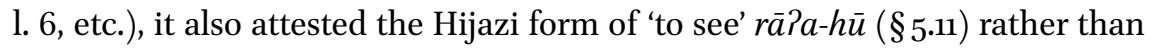
the textbook form ra?ā-hu ( $5 \mathrm{v}, 1.8)$. Even later, in a copy of Risālat ibn ?abī Zayd from 1059AH we find evidence of an-nubüpah 'prophecy' instead of the textbook an-nubuwwah (BnF Arabe 1058, 5v, l. 8), a form often considered to be a "hyperclassicism" (§6.5.1.1). Also, the dropping of hamzah in places where the textbook norms do not prescribe it is attested surprisingly late, e.g. mašizyatu$k a$ for mašlīatuka in a copy of al-Ǧazūlī's Dalāîl al-Xayrāt from $117 \mathrm{OAH}(\mathrm{BnF}$ Arabe 6859, 36r, l. 10).

\subsection{Conclusion}

I hope that this work has shown that there is still much to be discovered about the Quranic Arabic language, and that both Quranic Arabic, the reading traditions of the Quran and the emergence of the standard Classical Arabic deserve to be studied in their own right. I hope to have shown that the way we think about the language of the Quran needs to be approached from a (historical) linguistic point of view, and should be reframed not from a position where we anachronistically impose later standards onto the text, but starting from its primary source material: the Quranic Consonantal Text.

Undoubtedly much more is to be discovered. There are two main topics I wish to highlight here. First is the corpus of early Islamic papyri and inscriptions. These share many linguistic similarities with the language of the Quran, and should likewise be seen as products of their time. Deviations from the standard should not anachronistically be assumed to be deviations from the not yet established Classical Arabic standard, but instead should be compared against other documents of their time, including the QCT. Only this way we can deduce what the contemporary linguistic norms were.

Another question is the linguistic position of pre-Islamic and early Islamic poetry. The equation of the poetry with standard Classical Arabic and the language of the Quran all too often means that interesting linguistic variation that occurs in the poetry gets glossed over. These corpora deserve careful linguistic study in their own right. While certainly the poetry is much more linguistically mixed than other sources of early Arabic, it strikes me as likely that different 
poets from different regions are likely to use certain features more than others. The amount of times we must assume the loss of hamzah due to meter in the poetry of Ibn Rabī Rabīiah, as shown by Schwarz (1901), for example, is quite striking and should probably be seen in the context of him being a Hijazi poet. Any comments of this kind have mostly been impressionistic and incidental and a systematic linguistic study of the material is direly needed. 